\title{
IT IS NOT ABOUT PRODUCTIVITY; WELFARE IT IS ABOUT RIGHTS
}

\author{
Alexandre Godinho Bertoncello ${ }^{1}$, Gabriele Canali ${ }^{2}$ \\ ${ }^{1}$ Universidade do Oeste Paulista - UNOESTE, Presidente Prudente, SP, Brasil. ${ }^{2}$ Univertisà Cattolica del Sacro Cuore, \\ Itália. E-mail: bertoncello@unoeste.br
}

\begin{abstract}
We assume that the undernourishment or starvation continued in Sub-Saharan Africa (SSA) because there the misery persisted. Poverty reduction is the only way to the end hunger in Africa. Also, for an agricultural country in SSA the best way to solve the problem of poverty is through agricultural development. Our analysis is based upon a sample of nine countries in SSA, so called SSA - 9. SSA has around 47,5 percent of rural population in extreme poverty while between 1990 and 2005 when food prices were stable and low, extreme rural poverty in SSA involved around 64.6 percent of population. Thus, we have built up a model trying to answer to the question of how the agricultural gears in SSA - 9 were moving between 1990 and 2005 and assess how the agricultural growth could reduce rural poverty. We used a system of recursive rather than simultaneous equations: a recursive model is a special case of an equation system where the endogenous variables are determined one at a time in sequence. The most important result is that the main tools that had a strong relation with poverty reduction in SSA - 9 were legislation on property rights (PR), access to the credit system, Human capital and infrastructure.
\end{abstract}

Keywords: Sub-Saharan Africa; Poverty reduction; Recursive model

\section{NÃO É SOBRE PRODUTIVIDADE; BEM-ESTAR SOCIAL É SOBRE DIREITOS}

\section{RESUMO}

Assumimos que a desnutrição e a fome continuam na África Subsaariana (SSA), porque lá a miséria persiste. A redução da pobreza é o único caminho para o fim da fome na África. Além disso, para um país agrícola na SSA a melhor maneira de resolver o problema da pobreza é através do desenvolvimento agrícola. Nossa análise é baseada em uma amostra de nove países da SSA, assim chamados SSA - 9. SSA tinha cerca de 47,5\% da população rural em extrema pobreza, enquanto entre 1990 e 2005, quando os preços dos alimentos estavam estáveis e baixos, a extrema pobreza rural na SSA envolve cerca de $64,6 \%$ da população. Assim, construímos um modelo que tenta responder à questão de como as engrenagens agrícolas na SSA 9 moveram-se entre 1990 e 2005 e avaliar como o crescimento agrícola poderia reduzir a pobreza rural. Usamos um sistema de equação recursiva em blocos simultâneos: um modelo recursivo é um caso especial de um sistema de equações onde as variáveis endógenas são determinadas em uma sequência unitária. 0 resultado mais importante é que as principais ferramentas que tiveram forte relaça6o com a redução da pobreza na SSA - 9 foram a legislação sobre direitos de propriedade (PR), acesso ao sistema de crédito, capital humano e infraestrutura.

Palavras-chave: África Subsaariana; Redução da pobreza; Modelo recursivo.

\section{INTRODUCTIONS}

Agricultural growth always led an agricultural country to the development, but the elasticity of the result achieved by each one was different, because the labor force growth, GDP growth and poverty reduction all depend on inner factors. However, is truly striking that in a country that has relevant arable land and most of population working in agriculture, it has a better performance as far as the previous three items are concerned (table1), the so called "agricultural linkages". Small countries with a scarce quantity of arable land as Singapore, Hong Kong and Monaco are out of this rule, since the services sector led to their development. 
Table 1. SSA agricultural growth and GDP growth

\begin{tabular}{|c|c|c|c|}
\hline Agriculture growth & GDP growth & Country & \multicolumn{1}{|c|}{ Authors } \\
\hline $1 \%$ & $0.92 \%$ & 14 & \multirow{2}{*}{ M. Roemer and M. K. Gugerty 1997} \\
\hline $1 \%$ & $2.75 \%$ & Burkina Faso & \\
\hline $1 \%$ & $1.96 \%$ & Niger & \\
\hline $1 \%$ & $1.97 \%$ & Senegal & \multirow{2}{*}{ C. Delgado J Hopkins and V A Kelly 1998} \\
\hline $1 \%$ & $2.48 \%$ & Zambia & \multirow{2}{*}{ S Block and C P Timmer 1994 } \\
\hline $1 \%$ & $1.45 \%$ & Kenya & \\
\hline
\end{tabular}

Source: by author (2014)

All modern literature considers the linkages as part of the main tools to reduce poverty in rural areas around the world. We selected here fourteen examples of research made by western institutions and universities, which focused on developing countries localized in Latin America, Africa and Asia within a time series from 1960 to 2000s.

Some authors created models to explain this phenomenon, others supplied academic explanations with empirical results about agricultural growth and poverty reduction. However, all of them call attention to positive or negative effects that each inner factor could cause in an agricultural environment. In our model we substantially agree on the most popular ideas cited by these authors. The only exception is the inequality reduction issue.
Inequality reduction occurs as a consequence of various policies, and not as a result of the growth of the agriculture sector. At the beginning, agricultural growth in SSA meant increase of inequality, as illustrated by Bigsten (1984) in Kenya, Collier, Radwan and Wangwe (1986) in The U. R. of Tanzania, by Bigsten, Kayizzi-Mugerwa (1995) and Roemer and Gugerty (1997) in Uganda.

With the following two graphs, we are trying to summarise an immense quantity of ideas, referring to different situations, hence when one author talks about civil violence, other one in civil war or good democratic governments. We synthesized in the term "political stability" (PS), and so on (chart 1 and 2).

Chart 1. Authors with models

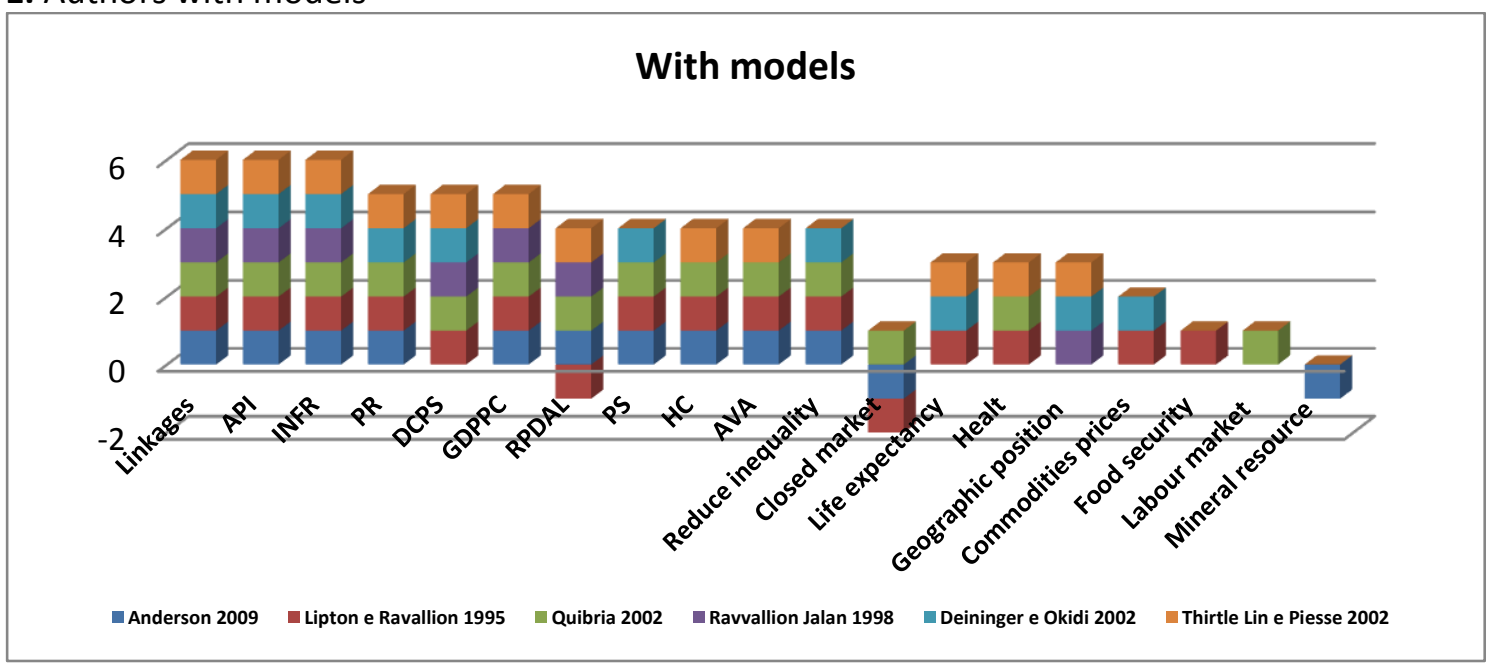

Source: author (2014). 
Chart 2. Authors without models

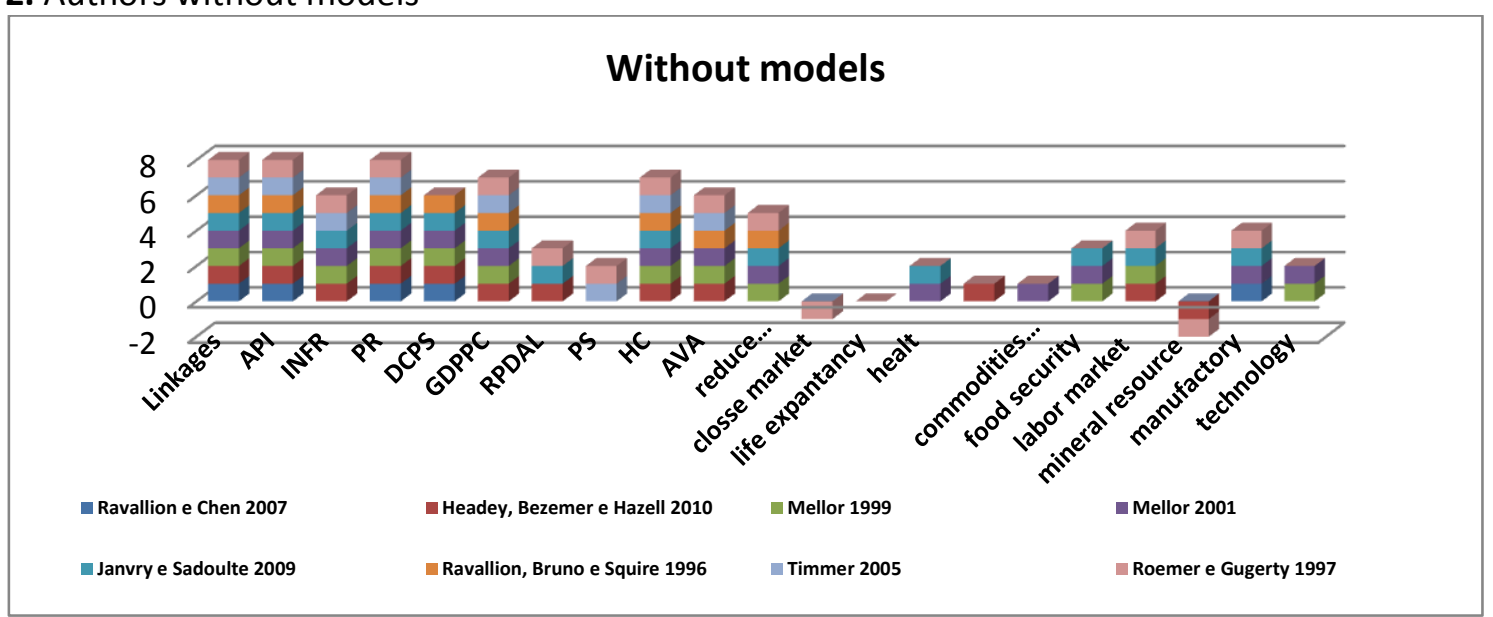

Source; author (2014).

Even though we agree with the authors about the main tools that help the poverty reduction in rural areas, these instruments do not have the same performances in SSA - 9 as in the rest of the world. We added NPKL elements and we did previous test with fixed-effects and pooled OLS econometric models, and unfortunately was confirmed the researcher concern that agricultural linkages are not working in SSA. The idea, here, is to reproduce the metothodoly used by previous authors but using other data and different countries (ANDERSON, 2009; LIPTON; RAVALLION, 1993; QUIBRIA, 2002; and THIRTLE LIN; PIESSE, 2003) since we have applied these models to the SSA -9 .

\section{METHODOLOGY}

Building up a model that answer how the agricultural gears in SSA - 9 were moving between 1990 and 2005, as well as assessing how the agricultural growth can reduce rural poverty, was very challenging. As we know, in the last 50 years the agricultural environment in SSA showed inability to build the linkages between farms and non-farming business in rural areas.

Also, they pointed out that aggregate production is virtually fixed and there is a balance of trade constraint, mainly for politics acts. Hence, it is transparent that there is not stimulus for farmers to increase productivity with nontradable goods; furthermore, political implications have locked the so called "agricultural linkages". Agricultural linkages are the economic relations between farmers and non-farmers businesses in rural areas, basically they are the services sectors such as the supply of manpower and sale of goods.
This happens because SSA countries have some asymmetric markets, and these do not allow development to follow like free market, again the SSA - 9 agriculture environments are suffering from non-tradable goods and cultural phenomena. So, the traditional model cannot explain this picture, so, to resolve this conundrum, we were looking for a model that gives details about agriculture mechanisms and indicates a solution.

It is widespread accepted and relativity easy to list these factors; in this research we suggested that agricultural development should start from the farmer and all factors that he can manage were called "dependent factors" or "endogenous factors" they are: education level so called human capital ( $\mathrm{HC})$, maintenance of the arable land and the efficiency of the crops.

The "independent" or "exogenous" factors, which have strong relation with endogenous factors, are: Political stability, land tenure system, macroeconomic policies, infrastructure and rural population density. Thus, a country which has an optimal combination between endogenous and exogenous factors reduced the poverty with a higher efficiency than others which have a shortage of such good combination.

Hence, we built a model that considers economic facts and also human behavior. It is clear that all the elements influence each other, so to understand this impact we used a system of recursive rather than simultaneous equations; a recursive model is a special case of an equation system where the endogenous variables are determined one at a time in sequence.

In others words, the left-hand side of the equation for the first endogenous variable 
includes no endogenous variables, only exogenous variables; the second endogenous variable includes exogenous variables and the first endogenous variable, the third endogenous variable includes exogenous variable the second endogenous variable, and so on, block by block. But the last endogenous variable influences the first block (figure 1).

First block; the land property right (PR) and political stability (PS) influence human capital at primary school (HCPRI).

Second block; the HCPRI, the percentile of agricultural value added of GDP (AVA), GDP per capita income (GDPPC) and the percentage of domestic credit to the private sector of GDP (DCPS) influence the soil loss of nitrogen, phosphorus and potassium elements (NPKL).

Third block; the NPKL, the rural population density by arable land (RPDAL) and the infrastructure index (INFR) influence the Agricultural gross per capita production index (API)

Fourth block, the API, RPDAL and PR influence the rural poverty line (RPL), similarly RPL and PR influenced the PS in first block doing a feedback loop.

Figure 1. Econometric model proposal

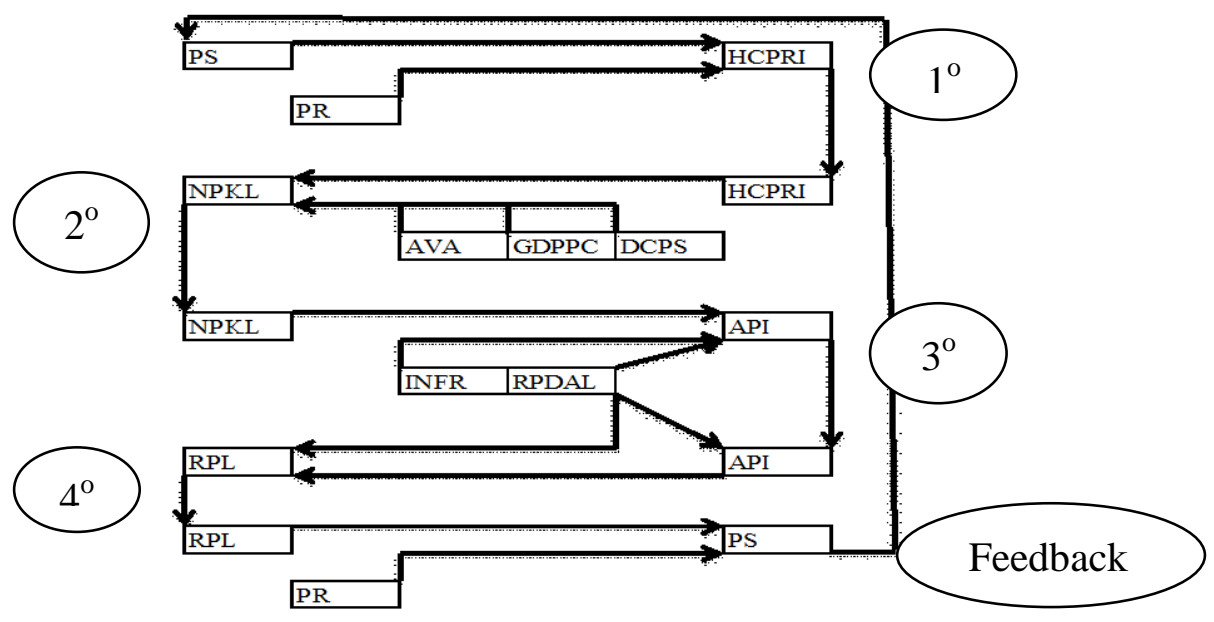

Source: author (2014)

\section{RESULTS}

We assumed that $\mathrm{HC}$ is narrowly influenced by political stability and land tenure system. The relationship between educational and economic system is very strong, in the economy the educational and cultural qualities obtained will transform economical values. World Bank (1998) proved it in empirical work about the world education and socioeconomic development, from 1960 to 1996 . However, this relationship is not working well in SSA countries. The GDP per capita of SSA had a negative growth -6.5 and the percentile of primary enrollment grew 87 percent among $1960-1996$.

On the other hand, the GDP per capita of the world grew 36 percent and the percentile of primary enrollment 19 percent. The world had a positive correlation and the SSA a negative correlation.

Although this is partly a season, why SSA countries had a different behaviour from the rest of the world in the past, we assumption that social and political instability were the roots of the problem throughout the years after independence. These countries lost $\mathrm{HC}$ with horrendous genocides or with successive migrations.

Psacharopoulos (1994), showed how difficult "HC stocks" mensuration, in a country, because people who improve their education level have more propensity to immigrate whether a country does not offer a well-off environment. So it is, people invest in your education if they believe in a future, and when the formative path finishes, they expect a good socio-economic environment to enjoy this investment. If the country has strong socio or political instability, people will invest less in education or will go away. In both cases the country loses the HC.

Our database measured years of school attainment, but we did not consider the quality of education, this research measured the local 
level of HC stocks. Albeit, each education system is only a continuation of family education and has the tendency to preserve the local values and the local culture. We would be important, in future works, to acknowledge the role of education quality.

Psacharopoulos and Patrinos (2004) confirmed that the improvement of the education level has benefices and great returns to investment, mainly in low and very low-income countries. This return occurs at a social level and with the so called "private returns" one's own reward is better than social returns.

Our sample has a per capita income lower than USD 1000, and it fits the very lowincome countries category. Thus, the social returns to investment in education represent 2,2 percent of investment per year in higher level, 2,24 percent in secondary level and 4,26 percent at primary level. The private returns are better than social returns. The own income growth is around 5,2 percent of investment per year in higher level, 2,85 percent in secondary level and 5,2 percent in primary level.

However, if the agricultural areas have more problems to improve the education level, farmers have great benefices in agriculture output per year of primary school. Many authors researched many countries in SSA, and all countries had a positive relation between education level and agricultural production (table 2).

Table 2. Education and agricultural output

\begin{tabular}{|l|c|}
\hline \multicolumn{1}{|c|}{ Area and Study } & $\begin{array}{c}\text { \% increased in agricultural output for 4 } \\
\text { years of primary schooling }\end{array}$ \\
\hline Kenya (BIGSTEN 1984) & 20 \\
\hline U. R. Tanzania (COLLIER, RADWAN and WANGWE 1986) & 19 \\
\hline Uganda (BIGSTEN and KAYIZZI-MUGERWA 1995) & 12 \\
\hline Uganda (APPLETON and BALIHUTA 1996) & 7 \\
\hline Zimbabwe (OWENS and HODDINOTT 1999) & 2 \\
\hline Ethiopia (WEIR 1999) & 20 \\
\hline
\end{tabular}

Source; by author (2014)

Consequently, the $\mathrm{HC}$, in rural areas, is led by farmer behaviours, because in a short or medium term it is unimaginably to see SSA governments make huge educational investments in rural areas. So, to overcome the "paradigm of stability", SSA governments should give SSA farmers the most important stimulus, that should make them feel safe and secure. Thereunto they should improve political stability and give the right to have a land or land tenure.

Political stability database in SSA 9 was taken from Center for Systemic Peace/Integrated Network for Social Conflict Research. This center created a task force that represents several of the US leading research institutions as Arizona State, Columbia, George Mason, Harvard, Maryland, Minnesota, Stanford and Texas universities ${ }^{1}$.

Land Tenure database in SSA 9, it was taken from International Property Rights Index (IPRI). It was built by World Bank Doing Business and World Economic Forum database. We picked

\footnotetext{
${ }^{1}$ See methodology on the site http://www.systemicpeace.org/
}

up variables of "Physical Property Rights", the protection of physical property rights and registering property that have a relation with property rights, because there does not exist a specific land tenure index in western institution. As a result, this index could not be perfect, but we analysed that is the best option to rank property rights in SSA -9.

Empirical works brought up that the top one increased in terms of sources accumulation and productivity, while the last one grew thanks to new opportunities of occupation and labour (BARRO and LEE, 1993). Our proposal was to find out tools, or so called "inner factors", that take people from rural areas away from extreme poverty conditions. Albeit all education levels compose the so-called $\mathrm{HC}$, for our sample we used only primary school level for three clear motivations.

\footnotetext{
${ }^{2}$ See methodology on the site

http://www.internationalpropertyrightsindex.org/data
} 
The gross enrolment ration relates to the total number of students at a given level the population of the age group that, according to national regulation or custom, would be enrolled at that level. The data set on educational attainment was supplied by UNESCO database and we used Barro and Lee ${ }^{3}$ methodology, but we considered only HC stocks by primary school or HCPRI.

$$
\mathrm{HCPRI} \equiv \mathrm{H}_{1 \mathrm{t}} / \mathrm{L}_{\mathrm{t}}
$$

$$
\mathrm{H}_{1 \mathrm{t}}=\mathrm{H}_{1 \mathrm{t}-5} *\left(1-\S_{\mathrm{t}}\right)+\mathrm{L} 18_{\mathrm{t}} *\left(1-\mathrm{PRI} \mathrm{I}_{\mathrm{t}-5}\right)
$$

$\S \mathrm{t} \approx\left(\mathrm{L}_{18 \mathrm{t}}+\mathrm{L}_{\mathrm{t}-5}-\mathrm{L}_{\mathrm{t}}\right) / \mathrm{L}_{\mathrm{t}-5}$

$\mathrm{H}_{1 \mathrm{t}}=\mathrm{H}_{1 \mathrm{t}} / \mathrm{L}_{\mathrm{t}}=\left[1-\left(\mathrm{L}_{1} \mathrm{t}_{\mathrm{t}} / \mathrm{L}_{\mathrm{t}} \mathrm{H}^{*} \mathrm{H}_{1 \mathrm{t}-\mathrm{5}}+\left(\mathrm{L}_{1} 8_{\mathrm{t}} / \mathrm{L}_{\mathrm{t}}\right) *\left(1-\mathrm{PRI} \mathrm{I}_{\mathrm{t}-5}\right)\right.\right.$

Where: HCPRI be result the quantity of $\mathrm{H}_{1}$ people that has primary school dived by $\mathrm{L}$ quantity of adult people or labour age (more than 18 years old); $\mathrm{H}_{1 \mathrm{t}-5}$ be the number of people within this adult population who have primary school; L18 be the population aged between 12 and 17 years old; PRI be the enrolment in primary school divided by total population aged between 6 - 11 years old; and $\S_{t}$ be the proportion of people aged 18 and over in year t-5 who did not survive to year $t$.

${ }^{3}$ See Barro and Lee 1993 International Comparisons of Educational Attainment 
Table 3. First block using fixed-effects

\begin{tabular}{|c|c|c|c|c|c|}
\hline \multicolumn{6}{|c|}{ Step 1: Fixed-effects, using 144 observations } \\
\hline \multicolumn{6}{|c|}{ Included 9 cross-sectional units } \\
\hline \multicolumn{6}{|c|}{ Time-series length $=16$} \\
\hline \multicolumn{6}{|c|}{ Dependent variable: HCPRI } \\
\hline & Coefficient & Std. Error & t-ratio & $p$-value & \\
\hline PS & 0.846789 & 0.302591 & 27.985 & 0.00590 & $* * *$ \\
\hline $\mathrm{PR}$ & 180.248 & 0.530459 & 33.980 & 0.00090 & $* * *$ \\
\hline \multicolumn{3}{|c|}{ R-squared } & \multicolumn{3}{|c|}{0.663631} \\
\hline \multicolumn{3}{|c|}{ Adjusted R-squared } & \multicolumn{3}{|c|}{0.638340} \\
\hline
\end{tabular}

Source: by author (2014)

\section{The second block: assessing soil quality}

We assumed that the NPKL is narrowly influenced by HCPRI, the agriculture value added (\% of GDP), GDP per capita income, human capital and Domestic credit to private sector (\% of GDP). To start up, agriculture needs basic conditions: soil, water and human intervention, but, to develop, it needs the improvement deriving from the use of the main natural assets; the soil should offer more productivity through good management practices and water supply, if necessary, should be regulated by irrigations or drainages.

Of course, low levels of inputs affect straight the crops yield, but, more importantly, they jeopardize the future agriculture of these regions, because they create a vicious circle. The yield gap reduces farmer's profit, hence the following year he will have fewer financial resources to invest and the lack of soil nutrient balance will lead to a deterioration of soil quality, thus reducing productivity, increased erosion processes and provoking a reduction of the arable land.

Thereby, knowing the amount of inputs needed is the milestone of the process. Thereunto it is fundamental to identify the quality of the soil to measure the investments. Ones of the first classifications of the African soil was made by Peterson (1987), who created one index. This index put on the table the quality and costs of lands around the world and compared it with the US soils and prices.

Even though it was useful, the index did not provide a thorough picture of the agricultural situation: soil quality is dynamic, and it is continuously changing, because the weather and agronomic activities have been influencing it all the time. In 1990 Smaling and Stoorvogel developed the "nutrient-budget" and "nutrientbalance" models, that to rely on a series of assumptions in order to deal with the complex nutrient systems.

Basically, the models or the so called "black box" account for the foremost macronutrients, nitrogen $(\mathrm{N})$, phosphorus $(\mathrm{P})$ and potassium (K) of the soil ${ }^{4}$. With five major inputs process of nutrients - IN 1 to 5 - and five principal outputs processes of nutrients - OUT 1 to 5 - were identified below. 
Figure 2. NPK "black box"

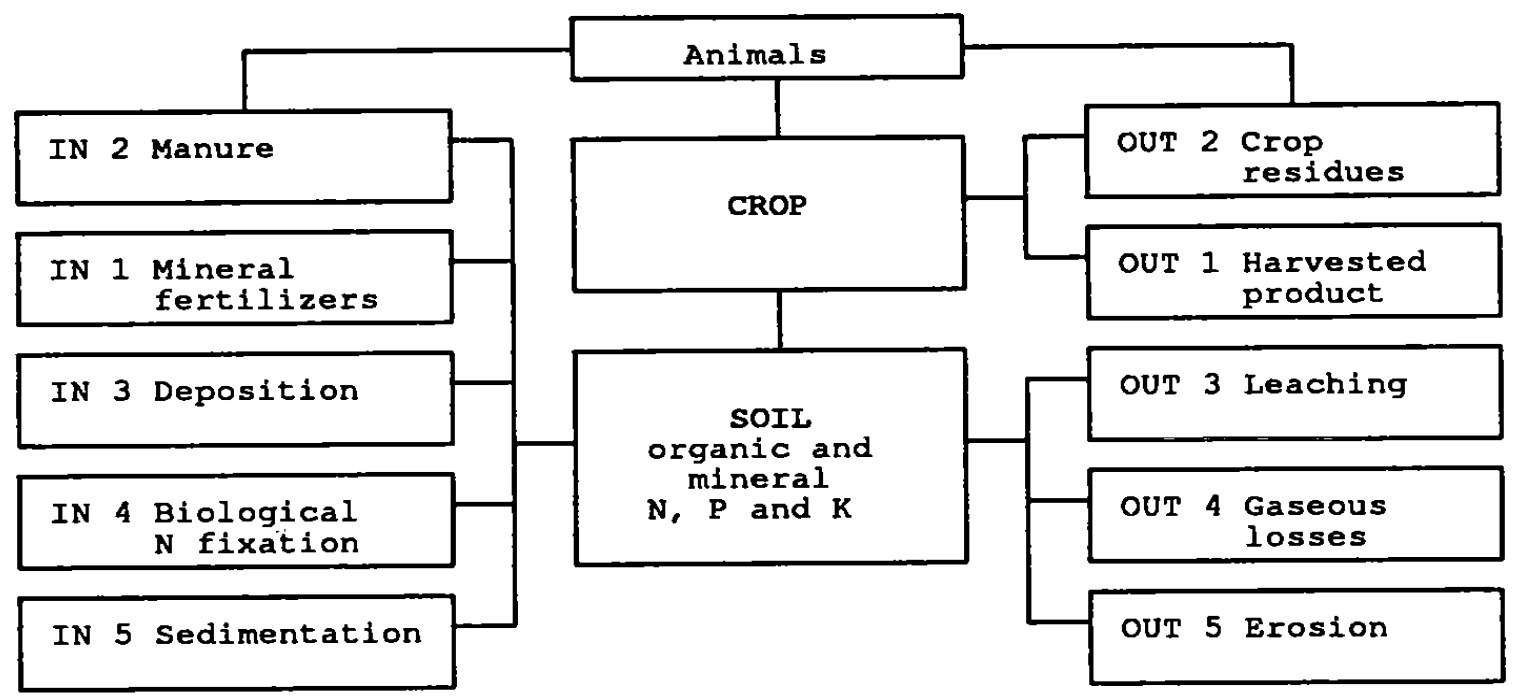

Source: Smaling and Stoorvogel (1990) pg 17

Despite the Smaling and Stoorvogel methodology is widespread accepted (COBO; DERCON; CADISCH, 2010; HENAO; BAANANTE, 2006; BINDRABAN; STOORVOGEL; JASEN; VLAMING; and GROOT, 2000; PIERI; DMANSKI; HAMBLIN; and YOUNG, 1995; and FAO 2003), the principal criticism is about the soil data base. As pivotal phase they used the "Land Use Systems" (LUS) and the "Land Use Type" (LUT) data base (FAO 1976). These data bases are more homogeneous and consequently we can use the same forms to calculation the nutrient balance, but they created problems when they were used for small land (micro level), because they are general data.

However, this research was looking for macro levels or national data, hence we assumptions that the Smaling and Stoorvogel methodology is the best model to understand which path the SSA -9 areas are following.

Here, fatefully, we confronted with the same problem; when you talk about African countries, there is a lack or mismatch of information about, for instance, inflation, employment and public investment. All these facts are "drivers" of social and economic movability.

To resolve this problem, we were picked up economics mobility to make up the lack of information, in others words, the agriculture value added in percentile of GDP (AVA). We considered that SSA's - 9 economy should follow the same trend of developed and emerging countries. As agriculture develops, it creates potentials for all country develops. Thus, the services and industrial sectors can gain space in their GDP and the percentile of agriculture value should decrease.

The rural areas in SSA - 9 historically have been losing NPK (NPKL), so the both facts, the agricultural development and NPKL, must have the inverse relation. While the NPK is negative agribusiness cannot develop well, and, as result economic movability cannot happen. On the other hand the percentile move of GDP means that macroeconomics data are improving and will influence farmer's deeds that will reduce NPKL.

Another fact that shows an inverse relation is the GDP per capita income (GDPPC); this is not a surprises for three reasons: Firstly, all SSA - 9 countries have a low per capita income, and the farmers use elementary agricultural techniques, like intensive labour forces; moreover they have poor infrastructure, that create difficulties to carry out national or international trades, hence they depend the local market. Therefore, the rise of income does not mean that the consumer market is improving: Usually in low income countries the consumer market is enlarged by demographic expansion.

The last issue, which is less complex and easier to deal with is the "dualism" economic theory, that does not work for SSA - 9; when the cost of labour force rises, farmers should invest in 
technology to use less workforce and rise the yield, but the farmer's investment to increase productivity are very few or do not exist in SSA 9.

We believe that low income countries have the same dilemma as median income countries; structural problems do not allow median income countries to turn into developed countries, the so called "middle income trap". The low-income countries paradigms are mainly education level $(\mathrm{HC})$ and credit systems.

With more education farmers can perform better analyses of the market and find out solutions and opportunities, however without credit systems, many opportunities will be lost, and the agricultural sector will have a low potential growth.

Whether AVA and per capita income have an inverse relation with NPKL, the HCPRI and domestic credit to private sector (DCPS) have a positive relation. The education level used in this step is the same methodology as the previous step.

We selected DCPS data from World Bank data bases, but unfortunately in these countries the rural credit does not have the same performances as the domestic credit to private sector in general. Frequently the agriculture credit represents a third of the performances. In others words, when the DCPS reaches 10 percent of GDP, the rural credit attains around 3 percent of agricultural GDP.

However, we were not sure whether to use this percentage, because, despite the extreme relevance of the issue, only IFAD reports have scarce data about rural credit, and using their information only we cannot build a time series data about rural credit. As a result, we maintained the reason about credit system but used the domestic credit of all the private sector, the so called DCPS (World Bank data).

As to the agricultural value added in percentile of GDP (AVA), and GDP per capita income (GDPPC) we used the World Bank data base, while for the human capital $(\mathrm{HC})$ we used the UNESCO data base.

Finally, for the NPKL data was used the Smaling and Stoorvogel (1990) data for 1983 and 2000, Henao and Baanante (2006) for 1995 and 2002 data. With "Smaling and Stoorvogel methodology" and FAOstat data, we created the NPKL 2009. So, we did a trend of NPKL among 1990 and 2005 in SSA - 9 through a median.

Table 4. Second block using fixed-effects

\begin{tabular}{|c|c|c|c|c|c|}
\hline \multicolumn{6}{|c|}{ Step 2: Fixed-effects, using 144 observations } \\
\hline \multicolumn{6}{|c|}{ Included 9 cross-sectional units } \\
\hline \multicolumn{6}{|c|}{ Time-series length = 16} \\
\hline \multicolumn{6}{|c|}{ Dependent variable: NPKL } \\
\hline & Coefficient & Std. Error & t-ratio & $p$-value & \\
\hline AVA & -0.797613 & 0.215273 & -37.051 & 0.00031 & *** \\
\hline GDPPC & -0.0384806 & 0.020262 & -18.992 & 0.05974 & * \\
\hline HCPRI & 0.176736 & 0.0969932 & 18.222 & 0.07071 & $*$ \\
\hline DCPS & 0.257647 & 0.172765 & 14.913 & 0.13828 & \\
\hline \multicolumn{3}{|c|}{ R-squared } & \multicolumn{3}{|c|}{0.874346} \\
\hline \multicolumn{3}{|c|}{ Adjusted R-squared } & & 0.862835 & \\
\hline
\end{tabular}

Source: by author (2014)

\section{The third block: assessing agricultural} productivity

We assumed that the agricultural productivity (API) is narrowly influenced by NPKL, rural population density by arable land (RPDAL), roads density and rail lines density (INFR). In this research we are looking for evidences that agriculture can reduce rural poverty as well as what tools are more efficient to optimizes this relation. For this, the third step is crucial to check the agriculture firms prospective within SSA - 9 contexts, i.e. what the capability of farmers are to increase productivity inside low income countries.

As everybody knows productivity does not means profit; to bring up the return of investment we should do the cost function and to kwon of constant returns to scale and efficiency 
performing a TFP analysis is more appropriated, therefore farmers can find out the breakeven point for their investment.

Thereunto we need information that does not exist, so, despite our caution when choosing the sample, some information about SSA countries had to be based on assumption. We hypothesized that, when yield growth of corps occurs, that reduces costs and farmers will have more profit, then they will reduce their level of poverty.

Many other authors did the same reasoning, when the agricultural sector grows in low income countries reduces the poverty (TIMMER, 2005; LIPTON; RAVALLION, 1993; MELLOR, 2001 and 1999; QUIBRIA, 2002; ROEMER; GUGERTY, 1997; ANDERSON, 2009; HEADEY; BEZEMER; and HAZELL, 2010; THIRTLE, LIN ; PIESSE, 2003). However, poverty reduction depends in part on the environment and the economy's poverty profile.

The rural population density is one of the key factors, because agriculture's powerful poverty reducing effect in rural areas come substantially through the links between farmers and non-farm activities (MELLOR, 2001), hence poor countries with poor infrastructure and high rural density can have better linkages in regional level, which means that high population density is better than low population density to develop non-farm activities.

Roemer and Gugerty (1997) emphasized the effect of rural density with some important research, supported by empirical results they said that large rural economies based on small scale farming, as in African and Asian countries, showed the different results in poverty reduction, because the countries with a high rural population density responded better than countries with a low rural population density.

Headey, Bezemer and Hazell (2010) put on the table not only the density of population but also the infrastructure system, they compared Latin American, Asian and African agricultural countries. Firstly, they confirmed that rural population density facilitated the startup of agriculture and accelerated the development of a rural non-farming economy, but these benefices turning into a problem when the countries had poor infrastructure.

On the other hand, African countries have exploited around a third of their agriculture area (FAO 2001); practically, only good quality soils were being used and the so-called marginal land were not used. Furthermore, in our sample, we have countries like Mozambique and Zambia that have almost a third of their areas truly unsustainable for agriculture.

Hence, we used the so called "rural population density of arable land" index (RPDAL) from the FAO data base. The RPDAL index was calculated, took all rural population and divided it by arable land used on base year

Identifying exactly the best combination between RPDAL and needs of infrastructure to support the agriculture development is a crucial point, but, once more, the absence of accurate data bases prevented us from doing a deeper analysis.

However, SSA - 9 has a narrow relation between API and RPDAL, as suggested by literature, but with negative effects, we therefore affirm, that despite the SSA's demographic windows, that it will has until 2050, their agriculture won't develop without investments in infrastructure. The most important investments would be logistic system as roads, rail lines and ports.

Notwithstanding their importance, between 1990 and 2005 international institutions practically did not assess the ports performances of SSA - 9. It is well known that ports are the most important tools to access international market and can helped the agricultural countries with a small domestic market to develop. However without the ports data, we sought for road and rail line data: the best free data base is the World Bank data base, but these data are at national level and we know that it would be better if we had the rural road density and the agricultural merchandises transported by railroad. 
Table 5. Third block using fixed-effects

\begin{tabular}{|c|c|c|c|c|c|}
\hline \multicolumn{6}{|c|}{ Step 3: Fixed-effects, using 144 observations } \\
\hline \multicolumn{6}{|c|}{ Included 9 cross-sectional units } \\
\hline \multicolumn{6}{|c|}{ Time-series length $=16$} \\
\hline \multicolumn{6}{|c|}{ Dependent variable: API } \\
\hline & Coefficient & Std. Error & t-ratio & $p$-value & \\
\hline NPKL & -0.11172 & 0.0569351 & -19.622 & 0.05184 & $*$ \\
\hline RPDAL & -0.0955184 & 0.0275439 & -34.679 & 0.00071 & $* * *$ \\
\hline INFR & 0.227076 & 0.212495 & 10.686 & 0.28719 & \\
\hline \multicolumn{3}{|c|}{ R-squared } & & \multicolumn{2}{|c|}{0.513679} \\
\hline \multicolumn{3}{|c|}{ Adjusted R-squared } & & 0.47315 & \\
\hline
\end{tabular}

Source: by author (2014)

\section{The fourth block: assessing the rural poverty}

We assumed that the Rural Poverty Line $(R P L)$ is narrowly influenced by API, RPDAL and land tenure system (PR). To get rid of misery, rural populations always have responded quickly for all stimuli. Classic and modern literatures, have indicated as main factors, RPDAL, PR and API. In the last step of the model we agree with the authors, but we highlighted that these exogenous elements, that influenced the reduction of rural poverty, affect and are affected by others "inner factors" and creating a feedbackloop.

Therefore, for SSA - 9 and probable for most of low-income agricultural countries, a higher RPDAL optimizes poverty reduction when API grows and PR improves, similarly the growth or reduction of API is affected by the mix of factors that can be positive or negative such as: RPDAL, local infrastructure and agro-ecological zoning (AEZ) in this model represented by the NPKL outputs.

NPKL was the outcome of the combination the natural resources as $A E Z$, the socio-economic environment by macroeconomic index and the intellectual capacity of farmers descripted in this thesis as human capacity (HC). In its turn HC has narrow linkages with PR and political stability.

In others words, the right of property or land tenure showed as pivot the process, but is not the essence. Poverty reduction happened in rural areas without PR, because in the core of this process is the fight against hunger of rural people.

Aided by techniques inherited from the local culture to manage the AEZ, "saved" by lack of infrastructure that prevents the entry of agricultural goods and forgotten by rulers when the soil does not have mineral resources, the farmers have been trying to improve their life conditions.

But we suggested that this circle is not sufficient to assure the rural poverty reduction; the governments of SSA - 9 should improve, first of all, land tenure system. That change would touch the rural population, the farmers would change their behaviour and the poverty reduction process would be more efficient.

Table 6. Fourth block using fixed-effects

\begin{tabular}{|c|c|c|c|c|c|}
\hline \multicolumn{6}{|c|}{ Step 4: Fixed-effects, using 144 observations } \\
\hline \multicolumn{6}{|c|}{ Included 9 cross-sectional units } \\
\hline \multicolumn{6}{|c|}{ Time-series length $=16$} \\
\hline \multicolumn{6}{|c|}{ Dependent variable: RPL } \\
\hline & Coefficient & Std. Error & t-ratio & $p$-value & \\
\hline API & -0.136445 & 0.0752567 & -18.131 & 0.07209 & $*$ \\
\hline PR & -130.882 & 0.350597 & -37.331 & 0.00028 & $* * *$ \\
\hline RPDAL & -0.019211 & 0.0257769 & -0.7453 & \multirow{2}{*}{\multicolumn{2}{|c|}{$\begin{array}{l}0.45743 \\
0.801489\end{array}$}} \\
\hline \multicolumn{4}{|c|}{ R-squared } & & \\
\hline \multicolumn{4}{|c|}{ Adjusted R-squared } & \multicolumn{2}{|c|}{0.784947} \\
\hline
\end{tabular}

Source: by author (2014) 
Results of the complete econometric Model

As we said, we built a model that considers economic facts and also human behavior. It is clear that all the elements influence each other, so to understand this impact we used a system of recursive rather than simultaneous equations, a recursive model is a special case of an equation system where the endogenous variables are determined one at a time in sequence.

In others words, the left-hand side of the equation for the first endogenous variable includes no endogenous variables, only exogenous variables, the second endogenous variable includes exogenous variables and the first endogenous variable, the third endogenous variable includes exogenous variable the second endogenous variable, and so on, block by block. But the last endogenous variable influences the first block.

One the most popular systems to create recursive and non-recursive models is the Structural Equation Models (SEM), because it allows to develop both confirmatory and exploratory modeling, meaning they are suited to both theory testing and theory development. Other attractive of SEM models is their simple causal interpretation that consents to identify direct and indirect effects.

The different between recursive and simultaneous models is that one simultaneous regression uses the independent elements as Xs and dependents variable $Y s$ and one equation explain the variance of $Y$ such as: $\boldsymbol{Y}_{\mathrm{i}}=\boldsymbol{B}_{\boldsymbol{0}}+\boldsymbol{6}_{1} \mathbf{X}_{\mathbf{1 i}}$ $+\boldsymbol{B}_{2} \mathrm{X}_{2 \mathrm{i}}+\boldsymbol{B}_{3} \mathrm{X}_{3 \mathrm{i}}+\varepsilon_{i}$

On the other hand, SEM model also used unidirectional causal effects, but they do it block by block, so they can evaluate the weight of each block as:

$$
\begin{aligned}
& Y_{i}=\sigma_{0}+\theta_{1} Y_{2 i}+\theta_{2} X_{1 i}+\varepsilon_{i} \\
& Y 2_{i}=\varnothing_{0}+\varnothing_{1} X_{1 i}+\varnothing_{2} X_{2 i}+\varnothing_{3} X_{3 i}+\varepsilon 1_{i}
\end{aligned}
$$

$\mathrm{X}_{\mathrm{i}}=\mathrm{C}_{0}+\mathrm{C}_{2} \mathrm{X}_{2 \mathrm{i}}+\mathrm{C}_{3} \mathrm{Y}_{\mathrm{i}}+\varepsilon \boldsymbol{2}_{i}$

For example; in a simple agriculture environment with supply and demand function:

Rainfall might affect the supply of agricultural goods, but it not directly affects the demand for then. Similarly, per capita income might affect demand but not directly affect supply. However, rainfall has an indirect influence on demand and per capita income also influences supply indirectly.

The SEM have been implicit in almost all of causal modeling. The SEM model started to be used for models of health / disease, but nowadays it is also used to model behaviour, economic systems and diseases.

In SEM, the qualitative causal assumptions are represented by the missing variables in each equation, as well as vanishing covariance among some error terms. These assumptions were tested in our research and to confirm our thesis. We used SEM by Stata software, again with follow assumptions;

First block; the land property right (PR) and political stability (PS) influence human capital at primary school (HCPRI).

Second block; the HCPRI, the percentile of agricultural value added of GDP (AVA), GDP per capita income (GDPPC) and the percentage of domestic credit to the private sector of GDP (DCPS) influence the soil loss of nitrogen, phosphorus and potassium elements (NPKL).

Third block; the NPKL, the rural population density by arable land (RPDAL) and the infrastructure index (INFR) influence the Agricultural gross per capita production index (API)

Fourth block, the API, RPDAL and PR influence the rural poverty line (RPL), similarly RPL and PR influenced the PS in first block doing a feedback loop. 
Figure 2. Results of the econometric model

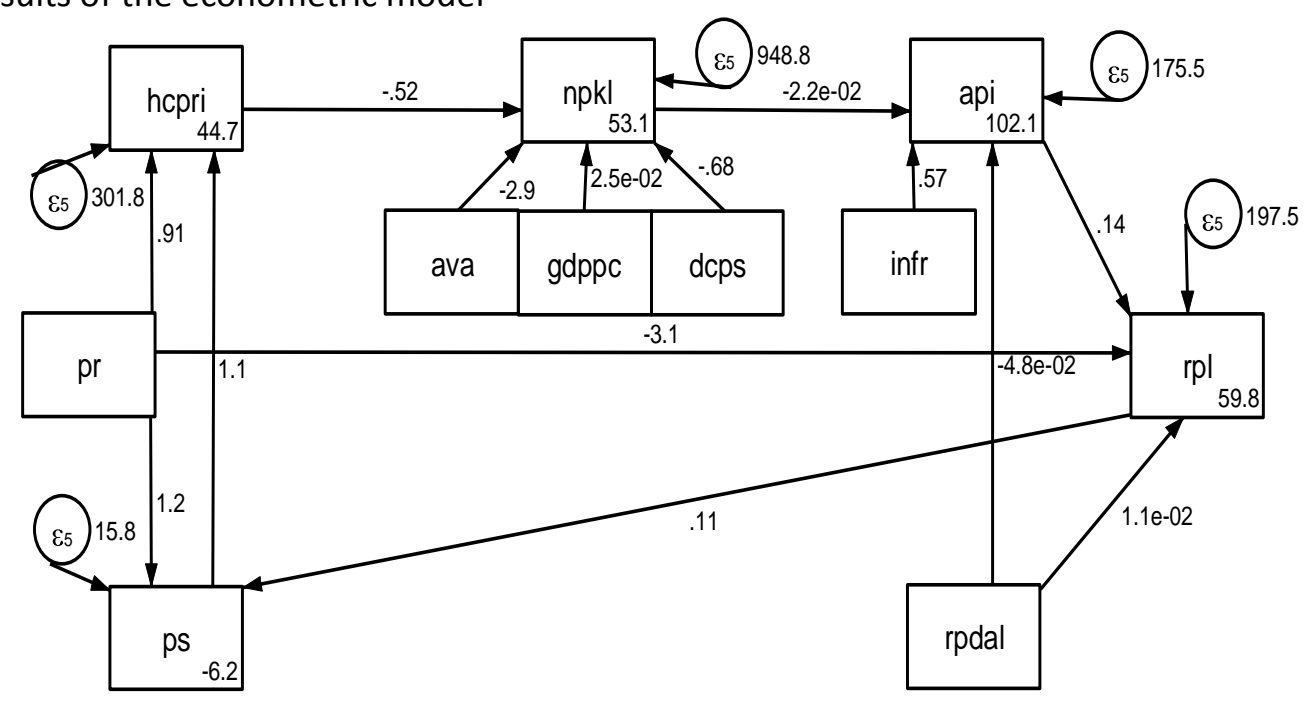

Source: by author (2014)

The estimated results the following; the first block the improvement in of 1 point of $P R$ and PS meant the improvement of HCPRI in 0.91 and 1.1 point respectively. This confirmed the classics school of human behaviours. As much as I feel safe and secure today, I will invest more for my future (Skinner and Maslow).

The second block showed that the loss of soil nutrient NPKL changed, when HCPRI, AVA and DCPS increase by one point in the following order $-0,52,-2,9$ and $-0,68$. With simple reasons we arrived in these conclusions: with the better education level, farmers acquired more knowledge to manage natural resources and to use new techniques, consequently the soil quality improved.

The decrease of agriculture value added in percentile of GDP (AVA) means that agriculture was following well and pulled out all national GDP, hence the other sectors of the country grew also, so the AVA index decreased. As a result, agriculture was doing well in the time it needed take care of soil quality. Finally, when the Domestic Credit to the private sector (DCPS) grows, it produces more possibilities to entrepreneurs, who can invest in fertilizers and improve soil quality.

However, the most interesting factor is that, when GDP per capita income (GDPPC) grows by one point the NPKL increases loss in 0.02 points. Literature points out that the "high cost of hired labour" in SSA induced farmers to hire less work force (DORMON; VAN HUIS; LEEUWIS; OBENG-OFORI; and SAKYI-DAWSON, 2004).

Even though it is not clear why this trend occurred, in this specific subject deeper research on the elasticity of supply and demand should be carried out. In others words, it should be investigated how much the earnings should increase to push the domestic demand and offset the worth paid to keep the soil quality.

The third block showed that, when NPKL and INFR progressed by one point meant 0,02 and 0,57 point of API enhancement correspondingly. On the other hand, when RPDAL increase by one-point API declined by 0,04 point.

In this step we should be open minded to understand the nuances of this tripod that was supporting API. First of all, NPKL is the collateral effect of the mixes between human intervention and the local natural resources. As we knew it can be positive, negative or equal to the NPK balances, i.e. if the farmers use fertilizer in excess this produces a positive NPK and causes pollution in the environment like many developed countries and nowadays some Asian countries.

If we get the equal balance of NPK, we will arrive the so called "sustainable agriculture". That means we will produce the max of goods possible without contaminating the soil and to ensure the future for the next generation.

On the other hand, what we have seen in SSA -9 and practically in all SSA countries in the last 20 years, is the NPKL phenomenon. The negative balance of NPK does not mean the slump the API like a cutting axe. NPKL is slowly weakening the foundations of current production and reducing the changes of future sustainability form an economic and social point of view. As a skin cancer that does not kill itself but kills because of its side effects. 
Infrastructure instead of NPKL has strong and quick effects: good roads and rail lines are the main link between regions and have a significant impact to reduce the costs and improve the trade of goods; it certainty can help farmers to leap from subsistence agriculture to cash crops trades (AMOATEY, 2007).

Furthermore, building infrastructure in marginal areas creates jobs and spreads welfare immediately. In our research we picked up only roads and rail lines data, but this maybe also true for energy and water supplies, health and telecommunication systems, and so on.

We called RPDAL the last foot of the tripod; when RPDAL is low the domestic agricultural development is less provable because it does not produce the linkages (Mellor 2001; Roemer; Gugerty 1997). On the other hand, a high RPDAL without adequate infrastructure blocks the agricultural development and it could be interpreted as a problem (HEADEY; BEZEMER; and HAZELL; 2010).

Our data confirm the strong relation between RPDAL and API, but also demonstrate that now in SSA - 9 this relation is negative. The increase of rural population stresses the NPK balance because the food demand continue to grow, but the infrastructure that can reduce this pressure is very poor to support the rural population growth.

Empirical results in Asia countries among 1960 and 2000 indicated that when infrastructure improved the high RPDAL converted into positive effect for API.

The fourth block; the rural poverty line (RPL) decrease very well when PR increase. The correlation amounting to more than one point of PR resulted in less 3.1 points of RPL, but the other two main factors had to inverse relationship. When RPDAL and API increased one point, the RPL also increased 0,01 and 0,14 point respectively.

With a title of land, the farmers have more security to work and produce more, can access to credit system and improve their business or yet they can sell their lands and go to the cities. In all these cases the index of RPL will fall.

The negative effect that RPDAL has on RPL was expected; some countries of SSA - 9 have low infrastructure as we saw from the previous block. Furthermore, the lack of land tenure system and the high birth rate produced the "micro-land" phenomenon or trap. The farms were divided between heirs but as was impossible to sell their land, the successors become ever more people to be supported by less land.

But API has a negative effect on RPL called our attention; this is the most import point in this research, in SSA - 9, when the API grew by one point, RPL increased by 0.14 . In others words the agricultural growth increased the rural poverty.

By a thorough analysis for each country of the sample, we saw one dichotomy of results; countries with low agricultural develop and good performance in poverty reduction as Uganda, or countries enjoying the improvement of API but with the rural poverty growing as Malawi.

It is because between 1990 and 2005 the prices of agriculture remained stable, thus the internal policies as land tenure, rural credit and infrastructure proved the main actors to optimize the agricultural results toward the rural poverty reduction.

Finally, in the feedback loop, PS level has inverse relationship with RPL in 0,11 point and positive linkage the PR in 1,2 points.

\section{REFERENCES}

AMOATEY C. T.; User Financed Road Infrastructure in Ghana: opportunities for road concessioning. Alemanha: Institute Fur Straben und Verkehrswesen University Stuttgart Germay, 2007.

ANDERSON K.; Five Decades of Distortions to Agricultural Incentives. Austrália: School of Economics University of Adelaide Australia, 2009. https://doi.org/10.1596/28167

APPLETON S.; BALIHUTA A.; Education and Agricultural productivity: evidence from Uganda). Journal of International Development, Estados Unidos, USA, v. 8, p. 415-444, 1996. https://doi.org/10.1002/(SICl)10991328(199605)8:3<415::AID-JID396>3.0.CO;2-9

BARRO R. J.; LEE J. W.; International Comparisons of Education Attainment, Journal of Monetary Economics, v. 32, p. 363-394, 1993. https://doi.org/10.1016/0304-3932(93)90023-9

BINDRABAN P.S.; STOORVOGEL J. J.; JASEN D. M.; VLAMING J. ; GROOT J. J. R. Land Quality Indicators for Sustainable Land Management: proposed method for yield gap and soil nutrient 
balance. Agriculture Ecosystems and Environment, v. 81, n. 2, p. 103-112, Elsevier. The Netherlands, 2000.

https://doi.org/10.1016/S0167-8809(00)00184-5

BIGSTEN A.; Education and Income Determination in Kenya. Journal of Development Economics, Estados Unidos, v.18, n. 2-3, p. 600-603, 1984. https://doi.org/10.1016/0304-3878(85)90087-2

BIGSTEN A. ; KAYIZZI-MUGERWA S.; Rural Sector Responses to Economic Crisis in Uganda. Journal of International Development, Estados Unidos, v. 7, p. 181-209, 1995.

https://doi.org/10.1002/jid.3380070202

COBO, J. G.; DERCON, G.; CADISCH, G.; Nutrient Balances in African Land Use Systems Across Different Spatial Scales: a review of approaches challenges and progress) Agriculture Ecosystems and Environment, v. 136, p. 1-15, Elsevier the Netherlands, 2010.

https://doi.org/10.1016/j.agee.2009.11.006

COLLIER P.; RADWAN S. ; WANGWE S. Labour and Poverty in Rural Tanzania: ujamaa and rural development in the United Republic of Tanzania, Oxford Claredon press USA, 1986.

DORMON, E. N. A.; VAN HUIS A.; LEEUWIS, C.; OBENG-OFORI D. ; SAKYI-DAWSON O. Causes of Low Productivity of Cocoa in Ghana: farmers' perspectives and insights from research and the socio-political establishment. NJAS - Wageningen Journal of Life Sciences. Legon Ghana: Faculty of Agriculture of Ghana, v. 52, n. 3/4, 2004. https://doi.org/10.1016/S1573-5214(04)80016-2

FAO. Assessment of Soil Nutrient Balance: approaches and methodologies, Rome Italy, 2003.

FAO. Mobilizing Resources to Fight Hunger. World Food Security Rome Italy, 2001.

FAO. A Framework for Land Evaluation Soil Bulletin. Rome Italy, 1976. n. 32.

HEADEY D.; BEZEMER D.; HAZELL P. B.; Agricultural Employment Trends in Asia and Africa: too fast or too slow?. The World Bank Research Observer, v.25, n. 1, p. 57-89, 2010. https://doi.org/10.1093/wbro/lkp028

HENAO J.; BAANANTE C.; Agricultural Production and Soil Nutrient Mining in Africa: implications for resource conservation and policy development. International Center for Soil Fertility and Agricultural Development (IFDC) Alabama- USA, 2006.

LIPTON M. ; RAVALLION M.; Poverty and Policy. Policy Research Department. The World Bank, Washington USA, 1993.

MELLOR J.; The relation Between Growth in Agriculture and Poverty Reduction, 1999.

MELLOR J. Rapid Employment Growth and Poverty Reduction, sectoral policies in Rwanda, Washington, 2001.

PETERSON W.; International Land Quality Indexes. Staff Paper 13877 Department of Agricultural and Applied Economics. University of Minnesota, 1987.

PIERI C.; DMANSKI J.; HAMBLIN A. ; YOUNG A. Land Quality Indicators. Washington, World Bank paper, n. 315, 1995. https://doi.org/10.1596/08213-3511-1

PSACHAROPOULOS G. Returns to Investment in Education: a global update. World Development, v. 22, n. 9, p. 1325 - 1343, 1994. https://doi.org/10.1016/0305-750X(94)90007-8

PSACHAROPOULOS G.; PATRINOS H. A. Returns to Investment in Education: a further update Education Economics, [online], v. 12, n. 2, aug., 2004.

https://doi.org/10.1080/0964529042000239140

QUIBRIA M. G.; Growth and Poverty: lessons from the East Asian miracle revisited. Asian Development Bank Institute MPRA. Munich Germany, 2002. paper n. 2638

ROEMER M. ; GUGERTY M. K. Does Economic Growth Reduce Poverty. CAERI Discussion Cambridge, 1997. paper n. 5.

SMALING E. M. A. ; STOORVEGEL J. J.; Assessment of Soil Nutrient Depletion in SubSaharan Africa: 1983 - 2000. The Winand Staring Centre Wageningen University the Netherlands, 1990. 
TIMMER C. P. Agriculture and Pro-poor Growth, lesson from Asia and the literature. Washington D.C., 2005.

https://doi.org/10.2139/ssrn.984256

THIRTLE C.; LIN L.; PIESSE J. The Impact of Research Led Agricultural Productivity Growth on Poverty in Africa, Asia and Latin America. Department of Environmental Science and Technology Imperial College of Science Technology and Medicine, 2003. https://doi.org/10.1016/i.worlddev.2003.07.001

WEIR S. The Effects of Education on Farmer Productivity in Rural Ethiopia. Center for the Study of African Economies. University of Oxford 1999. paper 99-7

WORLD BANK. World Development Indicator. Washington, 1998, ISBN 0-8213-3701-4124-3 A.

Recebido para publicação em 15/03/2019

Revisado em 23/04/2019

Aceito em 30/04/2019 